\title{
HUBUNGAN PENGETAHUAN TENTANG MENSTRUASI DENGAN SIKAP DALAM PENATALAKSANAAN DISMENORE PRIMER PADA REMAJA PUTRI DI SMAN 58 JAKARTA
}

\section{Correlation between Menstruation Knowledge and Attitude in the Primary Dysmenorrhea Management of Female Teens at SMAN 58 Jakarta}

\author{
Anggita Wijayanti ${ }^{1}$, Refirman DJ ${ }^{2}$, Sri Rahayu ${ }^{3}$ \\ 1,2,3Prodi Pendidikan Biologi Fakultas MIPA \\ Universitas Negeri Jakarta, Indonesia \\ email: anggita.wijayanti12@yahoo.co.id
}

\begin{abstract}
Primary dysmenorrhea was experienced by about $72.89 \%$ of young women in Indonesia. Primary dysmenorrhea is a common problem that often reported during their cycle. In other study, there are about $41.2 \%$ of young woman that choose to do nothing in order to reduce their pain. Therefore, knowledge about menstruation has big part for their attitude and practices to reduce and stop the pain caused by dysmenorrhea. This study aims to know the correlation between menstruation knowledge with attitude in the primary dysmenorrhea management. This study was done in November 2016 at SMAN 58 Jakarta, using descriptive method and correlation study survey technique. All of the class XII female student were used as the population, and 90 responden were taken using simple random sampling. The test showed that the data was homogen and have normal distribution. The regression model $Y=30.557+2.166 \mathrm{X}$ was significant and showed a linear correlation. Correlation coefficient obtained from hypothesis test was 0.762 . This result showed a strong and positive correlation between knowledge and attitude about primary dysmenorrhea in female student at SMAN 58 Jakarta
\end{abstract}

Keywords : knowledge, menstruation, attitude, management of primary dysmenorrhea 



\section{PENDAHULUAN}

Pada wanita, masa pubertas merupakan salah satu tahap perkembangan yang ditandai dengan kematangan organ seksual dan tercapainya kemampuan untuk bereproduksi. Kemampuan reproduksi tersebut ditandai dengan adanya ciri pertumbuhan primer. Ciri pertumbuhan primer ditunjukkan dengan terjadinya menstruasi pertama (menarche). Pada umumnya, menstruasi pertama dimulai antara umur 10 sampai 15 tahun. Menstruasi terjadi satu kali dalam sebulan sampai wanita mencapai usia 4550 tahun, hal ini tergantung pada kesehatan dan pengaruh lainnya (Desmita, 2006). Bagi sebagian besar wanita, menstruasi merupakan masalah yang serius karena mereka mengalami ketidaknyamanan secara fisik selama beberapa hari sebelum atau saat periode menstruasi berlangsung (Harel, 2006).

Ketidaknyamanan pada saat menstruasi disebabkan oleh adanya gangguan dalam siklus tersebut. Berbagai masalah menstruasi yang sering dikeluhkan para remaja, seperti ketidakteraturan menstruasi, menoragia, dismenore, dan gejala lain yang berhubungan (Singh dkk, 2008). Diantara berbagai keluhan tersebut, dismenore adalah yang paling umum dilaporkan terjadi pada 60\%-90\% remaja, dan merupakan penyebab paling sering ketidakhadiran di sekolah dan pengurangan aktivitas sehari-hari (Lestari dkk, 2010). Wanita merasakan nyeri atau kram perut saat menjelang menstruasi hingga 2-3 hari. Nyeri pada bagian bawah perut saat menstruasi disebut dismenore. Hal ini dapat mengganggu aktivitas sehari-hari. Dismenore didefinisikan sebagai nyeri uterus yang bersifat siklik yang terjadi sebelum atau selama menstruasi (Andriyani, 2013).

Angka kejadian dismenore yang terjadi pada remaja di Indonesia tahun 2009 terdiri dari 72,89\% mengalami dismenore primer dan 27,11\% mengalami dismenore sekunder (Proverawati dan Misaroh, 2009). Menurut Harel (2006), mayoritas dismenore yang terjadi pada remaja merupakan dismenore primer. Sementara menurut Lestari dkk. (2010), persentase remaja putri yang mengalami dismenore sebanyak 98,5 \% dan sebanyak 41,2\% remaja putri lebih memilih membiarkan saja rasa nyeri tersebut hilang dengan sendirinya. 
Selain itu, penelitian Kurniawati dan Kusumawati (2011), menunjukkan adanya pengaruh dismenore dalam penurunan aktivitas remaja putri disekolah. Lebih lanjut dikatakan Nelwati (2006), dalam penelitiannya bahwa remaja sangat memerlukan pengetahuan tentang menstruasi karena akan mempengaruhi psikis remaja dalam menghadapi menstruasi dan mempengaruhi respon terhadap nyeri.

Berdasarkan data yang diperoleh, siswi SMAN 58 seringkali izin untuk beristirahat di ruang UKS ketika mereka sedang menstruasi. Sebagian besar dari mereka menyatakan sakit perut karena sedang mengalami menstruasi. Di samping itu mereka juga mendapatkan materi pelajaran biologi mengenai menstruasi pada pokok bahasan sistem reproduksi. Berdasarkan hal tersebut, maka peneliti ingin melalukan penelitian mengenai "Hubungan Pengetahuan tentang Menstruasi dengan Sikap dalam Penatalaksanaan Dismenore Primer pada Remaja Putri di SMA Negeri 58 Jakarta".

\section{METODE PENELITIAN}

Penelitian ini menggunakan metode deskriptif dengan teknik survei melalui studi korelasional. Variabel bebas (X) pada penelitian ini adalah pengetahuan tentang menstruasi, sedangkan variabel terikat $(\mathrm{Y})$ adalah sikap dalam penatalaksanaan dismenore primer. Penelitian ini dilaksanakan di SMAN 58 Jakarta pada bulan november 2016. Populasi target dalam penelitan ini adalah seluruh remaja putri di SMA Negeri 58 Jakarta. Setelah dilakukan purposive sampling dengan menggunakan kriteria inklusi dan eksklusi didapatkan sampel sebanyak 116 responden. Berdasarkan rumus Taro Yamane, maka diperoleh sampel penelitian sebanyak 90 responden. Penentuan sampel siswa dilakukan dengan simple random sampling.

Kriteria inklusi pada penelitian ini diantaranya:

1. Remaja putri yang sudah menstruasi

2. Remaja putri yang mengalami tanda atau gejala dismenore primer

3. Remaja putri yang bersedia menjadi responden 
Kriteria eksklusi pada penelitian ini adalah:

1. Remaja putri yang mengalami gejala dismenore sekunder

2. Remaja putri yang tidak hadir saat peneltian berlangsung

Desain penelitian dalam penelitian ini yaitu :

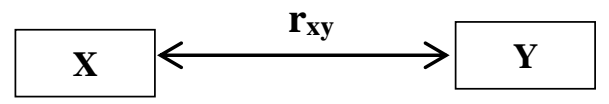

Keterangan:

$$
\begin{aligned}
\mathrm{X}= & \text { Pengetahuan tentang menstruasi } \\
\mathrm{Y}= & \text { Sikap dalam penatalaksanaan dismenore primer pada } \\
& \text { remaja putri kelas XII di SMAN } 58 \text { Jakarta } \\
\mathrm{r}_{\mathrm{xy}}= & \text { Korelasi variabel X terhadap } \mathrm{Y}
\end{aligned}
$$

Teknik analisis data yang digunakan yaitu dengan melakukan uji prasyarat analisis data dan uji hipotesis. Dalam uji prasyarat dilakukan uji normalitas dengan menggunakan rumus Kolmogorov-Smirnov pada $\alpha 0.05$ dan uji homogenitas dengan menggunakan uji Levene pada $\alpha$ 0.05. Sementara uji hipotesis dilakukan analisis model regresi sederhana, uji korelasi dengan rumus korelasi Pearson Product Moment,uji signifikansi dengan uji-t, serta perhitungan koefisien determinasi.

\section{HASIL PENELITIAN}

Berikut ini adalah hasil perhitungan distribusi frekuensi, kriteria skor dan persentase skor per dimensi dari masing-masing variabel, serta hasil data pendukung.

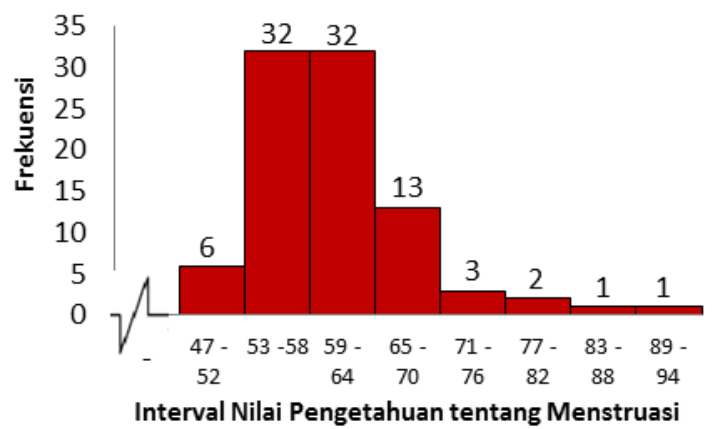

Gambar 1. Diagram batang distribusi frekuensi nilai pengetahuan tentang menstruasi pada remaja putri kelas XII di SMAN 58 Jakarta.

$4 \quad$ BIOTA: Jurnal Tadris IPA Biologi FITK IAIN Mataram 


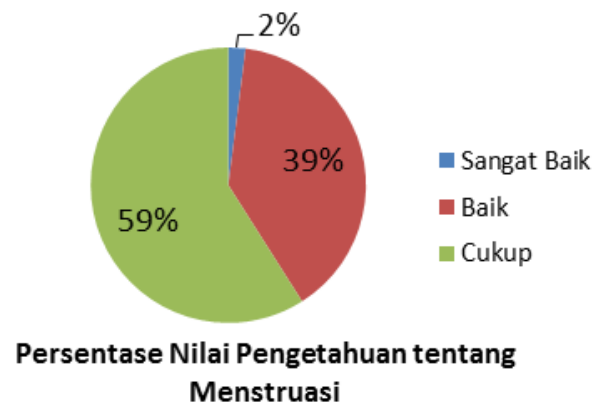

Gambar 2. Diagram lingkaran persentase jumlah siswa berdasarkan kategori penilaian pengetahuan menstruasi.

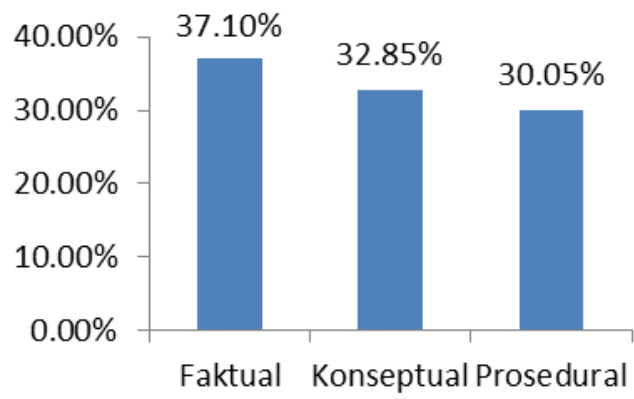

Gambar 3. Diagram Batang Persentase Nilai Rata-rata yang dicapai siswa pada dimensi pengetahuan.

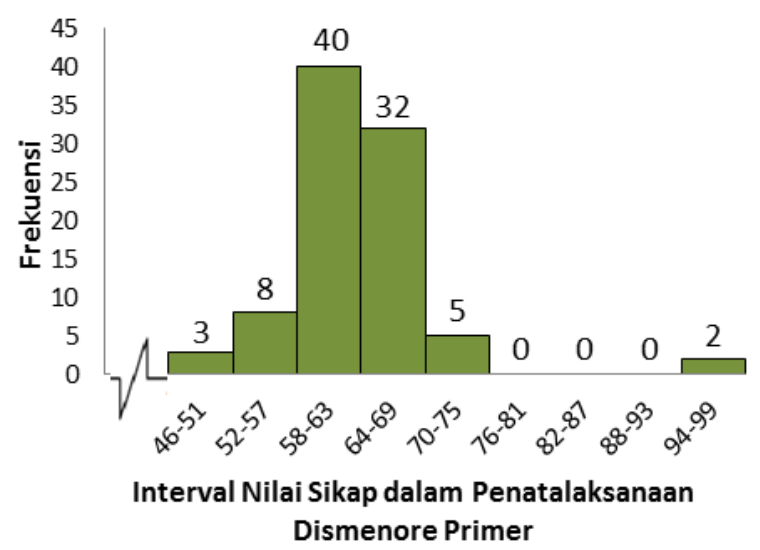

Gambar 4. Diagram Distribusi Frekuensi Sikap dalam Penatalaksanaan Dismenore Primer 


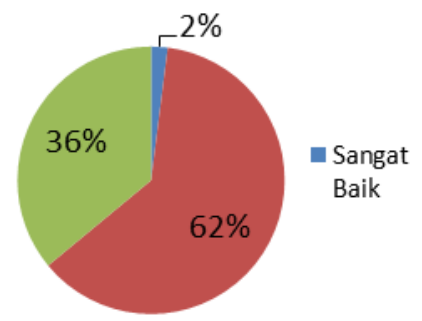

Persentase Nilai Sikap dalam

Penatalaksanaan Dismenore Primer

Gambar 5. Diagram Persentase Jumlah Siswa Berdasarkan Kategori Penilaian Sikap dalam Penatalaksanaan Dismenore Primer

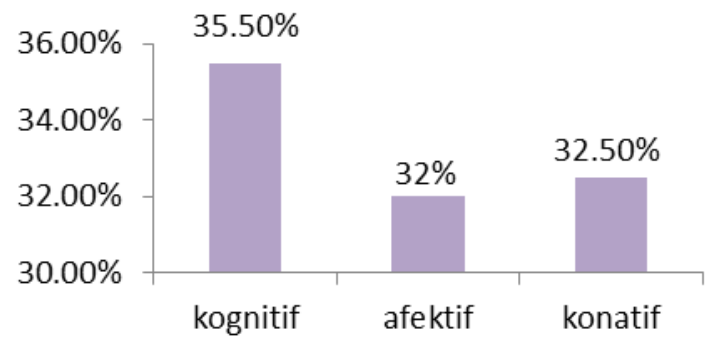

Gambar 6. Diagram Persentase Nilai Rata-Rata yang Dicapai Siswa Pada Komponen Sikap dalam Kuesioner Sikap Penatalaksanaan Dismenore Primer

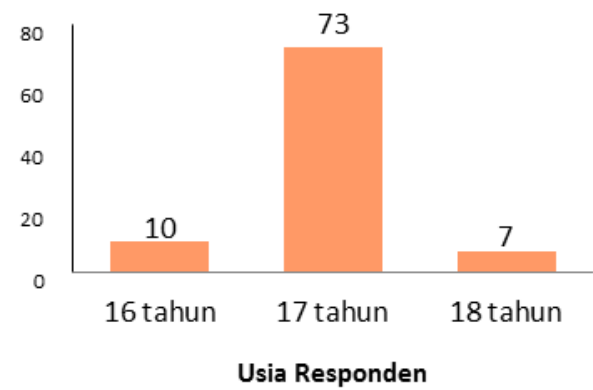

Gambar 7. Diagram Distribusi Usia Responden dari Remaja Putri Kelas XII di SMAN 58 Jakarta. 


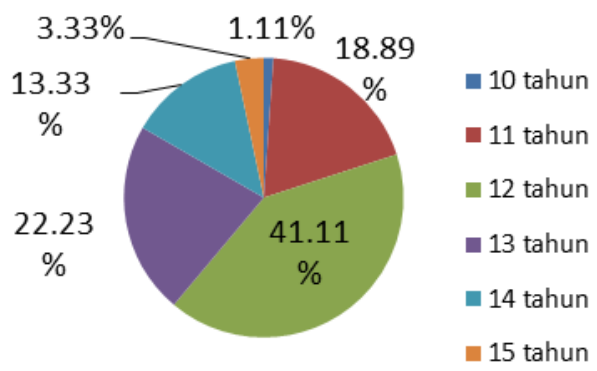

Persentase usia menarche responden

Gambar 8. Diagram Persentase Usia Menarche Responden

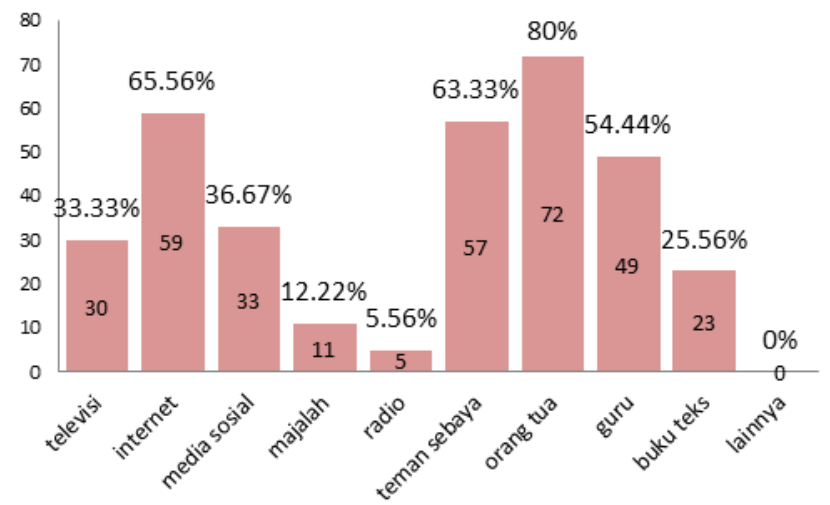

Sumber informasi responden mengenai menstruasi dan nyeri haid

Gambar 9. Diagram distribusi dan persentase sumber informasi responden.

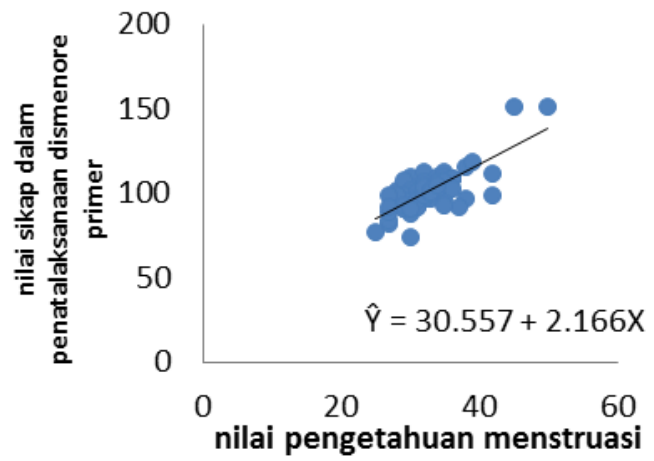

Gambar 10. Grafik model regresi antara nilai pengetahuan tentang menstruasi dengan nilai sikap dalam penatalaksanaan dismenore primer 
Berdasarkan perhitungan teknik analisis data, diperoleh data berdistrbusi normal dengan nilai signifikansi 0.051 dan homogen dengan nilai signifikansi 0.116 . Sementara pada analisis model regresi, diperoleh persamaan regresi $\hat{Y}=30.557+2.166 \mathrm{X}$. Berdasarkan hasil pengujian korelasi diperoleh $r_{x y}$ sebesar 0.762 yang berarti terdapat hubungan positif antara pengetahuan tentang menstruasi dengan sikap dalam penatalaksanaan dismenore primer pada remaja putri kelas XII di SMAN 58 Jakarta. Sementara nilai koefisien determinasi diperoleh sebesar $58.1 \%$.

\section{PEMBAHASAN}

Berdasarkan hasil penelitian, sebagian besar responden (59\%) dikategorikan memiliki pengetahuan yang cukup mengenai menstruasi. Hal ini menunjukkan bahwa seluruh remaja putri kelas XII di SMAN 58 Jakarta sebagai responden dalam penelitian telah mengetahui dan mempelajari mengenai menstruasi melalui pokok bahasan sistem reproduksi di sekolah mereka. Adanya perbedaan dalam nilai pengetahuan disebabkan oleh beberapa faktor. Menurut Notoatmodjo (2007) faktor-faktor yang memengaruhi pengetahuan antara lain pendidikan, pengalaman, usia, sumber informasi, lingkungan, dan status ekonomi.

Status pendidikan responden adalah sebagai pelajar kelas XII di SMAN 58 artinya mereka memiliki tingkat pendidikan yang sama namun kemampuan berpikir setiap individu dalam menerima pengetahuan atau menyerap materi pembelajaran berbeda-beda (Arikunto, 2006). Seluruh responden sudah mengalami menstruasi dan merasakan dismenore primer. Sebagian besar responden $(41,11 \%)$ mengalami menarche di usia 12 tahun. Dapat dikatakan bahwa sebagian besar responden mengalami menarche saat duduk di kelas VII SMP. Usia rata-rata responden saat ini sekitar 17 tahun sehingga rata-rata mereka sudah mengalami menstruasi kurang lebih selama 5 tahun.

Menurut Monks, Knoers, \& Haditono (2002), remaja merupakan suatu fase perkembangan antara masa kanak-kanak dan masa dewasa yang berlangsung dari usia 12 - 21 tahun. Berdasarkan penelitian, diketahui bahwa responden berusia ratarata sekitar 17 tahun. Dengan demikian, dapat diketahui bahwa 
responden termasuk kedalam usia remaja. Menurut Notoatmodjo (2007) usia memengaruhi daya tangkap dan pola pikir seseorang. Semakin bertambah usia akan semakin berkembang pula daya tangkap dan pola pikirnya, sehingga pengetahuan yang diperoleh akan semakin membaik.

Berdasarkan gambar 12, sumber informasi dominan yang dipilih responden diantaranya orang tua (80\%), internet $(65,56 \%)$ dan teman sebaya $(63,33 \%)$. Hal ini menunjukan bahwa orang tua, internet dan teman sebaya memiliki peranan yang paling besar sebagai sumber informasi responden mengenai pengetahuan tentang menstruasi dan nyeri haid. Berdasarkan hal tersebut memungkinkan responden untuk memiliki pengetahuan yang cukup mengenai menstruasi. Hal ini didukung oleh pernyataan Notoatmodjo (2007), bahwa sumber informasi seperti televisi, radio, majalah, koran dan buku tentunya dapat memberikan wawasan yang dapat memengaruhi pengetahuan seseorang.

Berdasarkan persentase nilai rata-rata responden mengenai menstruasi pada dimensi pengetahuan, dimensi faktual memperoleh persentase nilai rata-rata tertinggi yaitu sebesar 37,10\%. Hal ini menunjukan bahwa pengetahuan faktual adalah pengetahuan yang paling dikuasai oleh responden. Menurut Anderson dan Krathwohl (2015), pengetahuan faktual merupakan pengetahuan yang meliputi elemen-elemen dasar yang digunakan dalam menjelaskan, memahami, dan secara sistematis menata disiplin ilmu. Dalam kaitannya dengan penelitian ini, pengetahuan faktual meliputi definisi dan istilah yang terdapat dalam pengetahuan menstruasi.

Hasil penilaian sikap responden menunjukan bahwa sebagian besar responden memiliki nilai sikap penatalaksanaan dismenore primer baik yaitu sebanyak 56 responden (62\%). Sementara kategori cukup sebanyak 32 responden (36\%), dan sangat baik sebanyak 2 responden (2\%). Sedangkan sebagian besar nilai pengetahuan menstruasi responden termasuk ke dalam kategori cukup sebanyak 53 responden (59\%). Pengetahuan memegang peranan penting dalam menentukan sikap (Notoatmodjo, 2007). Namun ada hal lain yang juga dapat menentukan sikap salah satunya adalah adopsi. 
Selain itu, sikap penatalaksanaan dismenore primer dapat dipengaruhi oleh berbagai hal. Menurut Azwar (2007), orang lain yang dianggap penting, media massa, dan lembaga pendidikan merupakan faktor-faktor yang dapat memengaruhi sikap. Pengaruh orang lain yang dianggap penting seperti orangtua, guru, teman sebaya, tentu dapat membentuk sikap dalam penatalaksanaan dismenore primer yang baik dalam diri responden. Pengaruh tersebut dapat berupa pemberian contoh atau pengalaman mengenai sikap penatalaksanaan dismenore primer seperti berolahraga ringan, mengompres perut dengan air hangat, relaksasi, pemberian obat analgesik dan anti inflamasi. Hal ini didukung dengan pernyataan Azwar (2007), bahwa pada umumnya individu cenderung memiliki sikap yang konformis atau searah dengan sikap seseorang yang dianggapnya penting.

Media massa baik cetak maupun elektronik merupakan merupakan sumber informasi yang dapat diterima oleh masyarakat. Media massa yang menginformasikan masalah kewanitaan seperti menstruasi, nyeri haid, penanganan nyeri haid, tips dan trik dapat menambah wawasan responden sehingga dapat meningkatkan sikap penatalaksanaan dismenore primer. Hal ini seperti yang di kemukakan oleh Azwar (2007), bahwa media massa memberikan informasi yang bersifat sugestif yang dapat mengarahkan opini seseorang. Media massa memberikan landasan kognitif dan akan menimbulkan pengaruh afektif yang kemudian akan mempengaruhi arahan sikap seseorang.

Berdasarkan nilai sikap penatalaksanaan dismenore primer, nilai komponen kognitif paling tinggi memperoleh presentase sebesar 35,5\%. Komponen kognitif berisi persepsi, kepercayaan, dan sudut pandang yang dimiliki responden mengenai sesuatu (Azwar, 2007).

Berdasarkan hasil penelitian, nilai koefisien korelasi sebesar 0,762. Hal ini menunjukkan bahwa kekuatan hubungan antara pengetahuan tentang menstruasi dengan sikap dalam penatalaksanaan dismenore primer termasuk ke dalam kategori tinggi. Hasil penelitian ini juga menunjukkan adanya hubungan yang positif antara pengetahuan tentang menstruasi dengan sikap dalam penatalaksanaan dismenore primer. Hasil penelitian ini sejalan dengan penelitian yang dilakukan Khotimah dkk (2014) 
yang mengatakan bahwa terdapat hubungan yang positif antara pengetahuan tentang menstruasi dengan sikap menghadapi dismenore.

Berdasarkan hasil penelitian, diketahui terdapat 2 (2\%) responden yang memperoleh nilai pengetahuan sangat baik dengan sikap yang sangat baik, 35 (39\%) responden mendapat nilai pengetahuan baik dengan nilai sikap baik dan 53 (59\%) responden mendapat nilai pengetahuan cukup baik dengan nilai sikap cukup baik. Hal ini menunjukkan bahwa semakin baik pengetahuan tentang menstruasi maka sikap penatalaksanaan dismenore primer juga akan semakin baik. Hal ini didukung oleh pernyataan Notoatmodjo (2007) bahwa pengetahuan memegang peranan penting dalam pembentukan suatu perilaku dan terdapat hubungan antara pengetahuan dengan perilaku seseorang, dalam hal ini pengetahuan tentang menstruasi yang dimiliki siswa akan diproses dalam dirinya dan menjadi suatu kepercayaan sehingga membentuk sikap dalam penatalaksanaan dismenore primer.

Namun, berdasarkan hasil penelitian ditemukan juga hasil yang berbeda. Terdapat 53 (59\%) responden memiliki nilai pengetahuan yang cukup dengan nilai sikap yang baik yang ditemukan pada 56 (62\%) responden. Hal ini menunjukkan terdapat faktor-faktor lain yang memengaruhi sikap dalam penatalaksanaan dismenore primer seperti orang lain yang dianggap penting, media massa, lembaga pendidikan, dan pembentukan sikap secara adopsi.

Untuk mengetahui seberapa besar kontribusi pengetahuan tentang menstruasi dalam pembentukan sikap dalam penatalaksanaan dismenore primer maka dilakukan perhitungan koefisien determinasi. Berdasarkan hasil perhitungan, diketahui bahwa nilai koefisien determinasi 58,1\%. Hal tersebut menunjukkan pengetahuan tentang menstruasi memberikan kontribusi sebesar $58,1 \%$ terhadap sikap dalam penatalaksanaan dismenore primer, sedangkan 41,9\% disebabkan oleh faktorfaktor lain. Menurut Azwar (2007), faktor lain yang mempengaruhi sikap seseorang yaitu pengaruh orang lain, media massa, kebudayaan, pengalaman pribadi, emosi dan lembaga pendidikan. 


\section{KESIMPULAN}

Kesimpulan dari hasil penelitian ini adalah terdapat hubungan antara pengetahuan tentang menstruasi dengan sikap dalam penatalaksanaan dismenore primer pada remaja putri kelas XII di SMAN 58 Jakarta. Dimana hubungan tersebut adalah hubungan positif yang dinyatakan dengan nilai koefisien korelasi $\left(r_{\mathrm{xy}}\right)$ sebesar 0.762. Berdasarkan hasil perhitungan, diketahui bahwa nilai koefisien determinasi sebesar 58,1\%. Hal tersebut menunjukkan pengetahuan tentang menstruasi memberikan kontribusi sebesar 58,1\% terhadap sikap dalam penatalaksanaan dismenore primer.

\section{DAFTAR PUSTAKA}

Anderson dan Krathwohl. (2015). A Taxonomy for Learning, Teaching, and Assessing (A Revision of Bloom's Taxonomy of Educational Objectives). Abridge Edition. New York: McKay Company

Andriyani, A. (2013). Panduan Kesehatan Wanita. Solo: As-Salam Group.

Arikunto, S. (2006). Dasar-Dasar Evaluasi Pendidikan. Jakarta: Rineka Cipta.

Azwar, S, M.A. (2007). Sikap Manusia Teori dan Pengukurannya, edisi 2, Yogyakarta: Pustaka Pelajar.

Desmita. (2006). Psikologi Perkembangan. Bandung : PT. Remaja Rosdakarya.

Harel, Zeev. (2006). Dysmenorrhea in Adolescents and Young Adult: etiology and Management. Pedriatic Adolescents Gynecology Journal: 363-371.

Khotimah, Husnul., Kimantoro., Cahyawati Fitrianingsih. (2014). Pengetahuan remaja Putri tentang Menstruasi dengan

12 BIOTA: Jurnal Tadris IPA Biologi FITK IAIN Mataram 
Sikap Menghadapi Dismenore Kelas XI di SMA Muhammadiyah 7, Yogyakarta. Jurnal Ners dan Kebidanan Indonesia. 2(3):136 - 140

Kurniawati, Dewi dan Kusumawati, Yuli. (2011). Pengaruh Dismenore terhadap Aktivitas pada Siswi SMK. Jurnal Kesehatan Masyarakat Universitas Muhammadiyah Surakarta, Indonesia.

Lestari, Hesti., Metusala, Jane., dan Suryanto D.Y. (2010). Gambaran Dismenorea pada Remaja Putri Sekolah Menengah Pertama di Manado. 12(2).

Monks F.J, Knoers A.M.P., Haditono S.R. (2002). Psikologi Perkembangan Pengantar dalam Berbagai Bagiannya, Edisi Keempat Belas. Yogyakarta: Gadjah Mada University Press.

Nelwati. (2006). Hubungan Antara Pengetahuan Tentang Menstruasi Dengan Derajat Nyeri Dismenorea Pada Remaja Putri Di Kota Padang. Journal of Indonesia Nursing, University of Indonesia. Vol. 10.

Notoatmodjo, S. (2007). Promosi Kesehatan \& Ilmu Perilaku. Jakarta: Rineka Cipta.

Proverawati, A \& Misaroh, S. (2009). Menarche Menstruasi Pertama Penuh Makna. Yogyakarta: Nuha Medika

Singh A, Kiran D, Singh H. (2008). Prevalence and severity of dysmenorrhea: a problem related to menstruation, among first and second year female medical students. Indian Physiology and Pharmacology journal. 52:389-97. 